\title{
PERAN PERBANKAN DALAM PENCEGAHAN PENDANAAN TERORISME
}

\author{
Erwin Asmadi \\ Fakultas Hukum Universitas Muhammadiyah Sumatera Utara \\ E-mail: erwin.asmadi@gmail.com
}

\begin{abstract}
Funding is very essential as a forerunner to an act of terrorism because its propaganda product requires significant cost for the mobility, tools that are used as well as the ease-run actors to refrain from the pursuit of law. By this prevention, terrorism could be hampered by itself. Law Number 9 of 2013 concerning Prevention and Eradication of Crimes of Financing of Terrorism and other Laws give authority for banking to do prevention action for eradicating the terrorism mobility.
\end{abstract}

\section{Kata Kunci: Perbankan, Dana, Terorisme.}

\section{A. Latar Belakang}

Terorisme adalah suatu permusuhan yang ditekuni oleh individu-individu, kelompok-kelompok atau negara-negara dengan penuh kesewenang-wenangan terhadap manusia (agama, darah, akal, harta dan kehormatannya). Terorisme tersebut mencakup berbagai bentuk pemunculan tanpa haq serta sesuatu yang berkaitan dengan bentuk-bentuk permusuhan, membuat ketakutan di jalan-jalan, membajak dan segala perbuatan kekerasan dan ancaman (Sunusi 2010: 126-127).

Maraknya aksi terorisme yang terjadi dengan jatuhnya banyak korban telah mengidentifikasi bahwa terorisme adalah sebuah kejahatan terhadap nilainilai kemanusiaan (Soeharto 2007: 2), karena akibat terorisme telah menghilangkan nyawa tanpa memandang korban dan menimbulkan ketakutan masyarakat secara luas, atau hilangnya kemerdekaan serta kerugian harta benda, sehingga dikategorikan sebagai extra ordinary crime (Soeharto 2007: 5), maka perlu dilaksanakan langkah-langkah pemberantasannya.

Pemberantasan merupakan bagian dari penanggulangan kejahatan melalui politik kriminal atau kebijakan hukum pidana (criminal policy) yang secara garis besar dilakukan dengan dua cara, yakni melalui cara penal dan melalui cara 
nonpenal (Mardenis 2011: 79). Penanggulangan kejahatan melalui cara penal, lebih menitikberatkan pada sifat repressive yakni berupa penindasan atau pemberantasan atau penumpasan sesudah kejahatan terjadi, sedangkan cara nonpenal, lebih menitikberatkan pada sifat preventive yakni berupa pencegahan atau penangkalan atau pengendalian sebelum kejahatan terjadi (Sudarto 1981: $118)$.

Penanggulangan kejahatan melalui pendekatan nonpenal dilakukan dengan cara pencegahan tanpa pidana (prevention without punishment) dan mempengaruhi pandangan masyarakat mengenai kejahatan dan pemidanaan lewat media masa (influencing views of society on crime and funishment/mass media) (Mardenis 2011: 79). Salah satu caranya adalah dengan mengesahkan serta menerapkan aturan pemberantasan terorisme atau pencucian uang dalam rangka mempersempit ruang gerak pendanaan terorisme.

Pendanaan sangat penting sebagai cikal bakal lahirnya tindakan terorisme sebab produk propagandanya memerlukan biaya yang cukup besar bagi pergerakan (mobilitas), alat (tools) yang dipergunakan serta kemudahan yang dijalankan pelaku untuk menghindarkan diri dari pengejaran aparat penegak hukum. Pergerakan pelaku menyangkut ruang geraknya yang dapat melintas batas negara (transnasional) dan alat yang digunakan, seperti bom tidak mungkin dapat dibeli dengan harga yang murah. Sehingga dengan dilakukannya pencegahan atas pendanaan terorisme, ruang gerak pelaku dan tindakan terorisme dengan sendirinya akan terhambat. Undang-undang Nomor 9 Tahun 2013 tentang Pencegahan dan Pemberantasan Tindak Pidana Pendanaan Terorisme (selanjutnya disingkat UU No. 9 Tahun 2013), dalam Pasal 1 Angka 1 ditentukan bahwa pendanaan terorisme adalah segala perbuatan dalam rangka menyediakan, mengumpulkan, memberikan, atau meminjamkan dana, baik langsung maupun tidak langsung, dengan maksud untuk digunakan dan/atau yang diketahui akan digunakan untuk melakukan kegiatan terorisme, organisasi teroris, atau teroris.

Rumusan defenisi pendanaan terorisme UU No. 9 Tahun 2013 tersebut, menyiratkan adanya peran pihak-pihak yang secara aktif melakukan suatu perbuatan. Perbuatan yang dikategorikan dalam pendanaan terorisme tersebut 
antara lain: menyediakan, mengumpulkan, memberikan atau meminjamkan dana. Salah satu media yang selalu dimanfaatkan dalam menyediakan, mengumpulkan, memberikan, atau meminjamkan dana adalah pihak perbankan. Perbankan adalah media yang rentan digunakan dalam pembiayaan tindak pidana terorisme, sehingga perlu soliditas pengawasan yang baik dan transparan sehingga secara proaktif membendung pembiayaan kegiatan terorisme (Purwanto 2010: 28). Berdasarkan uraian ini, maka dapat dikatakan bahwa perbankan memainkan peranan untuk melakukan pencegahan terhadap pendanaan tindak pidana terorisme. Oleh sebab itu perlu dilakukan kajian yang bertujuan untuk mengetahui peran perbankan dalam pencegahan pendanaan terorisme.

\section{B. Metode Penelitian}

Jenis penelitian hukum dapat dibedakan menjadi penelitian hukum normatif dan penelitian hukum empiris/sosiologis. Penelitian hukum normatif merupakan penelitian yang datanya bersumber pada data sekunder dan berhubung data penelitian ini adalah data sekunder, maka termasuk dalam jenis penelitian hukum normatif. Sifat penelitian ini adalah deskriptif, yang bertujuan untuk memberikan gambaran tentang gejala-gejala sosial yang terkait dengan masalah pendanaan teroris. Sumber data penelitian berupa bahan hukum primer, bahan hukum sekunder dan bahan hukum tersier. Metode pengumpulan data dilakukan menggunakan teknik studi dokumen, yang dianalisis dengan menggunakan teknik analisis kualitatif.

\section{Hasil Penelitian dan Analisis}

\section{Ruang lingkup tindak pidana terorisme}

Ruang lingkup ini dikemukakan agar diperoleh batasan yang jelas terhadap defenisi terorisme, walaupun memang defenisi tentang terorisme belum mencapai kesepakatan yang bulat dari semua pihak karena di samping banyak elemen terkait juga dikarenakan semua pihak berkepentingan melihat atau menterjemahkan permasalahan (term of terorism) dari sudut pandang kepentingan masing-masing. Hal tersebut seperti yang dikemukakan oleh Laquer dengan menyatakan: "No 
definition of terrorism can possibly cover all the varieties of terrorism that have appeared throughout history. Such a definition does not exist nor will it be found in the foreseeable future" (Hendropriyono 2009: 31).

Hingga sekarang tidak ada definisi mengenai terorisme yang digunakan secara universial karena masih ada berbagai interpretasi tentang pengertian teror, teroris dan terorisme (Petrus Reinhard Golose 2009: 1), tetapi guna memperoleh pemahaman terhadap pengertian terorisme secara konsisten, perlu dikemukakan pengertian tentang terorisme tersebut, baik yang berasal dari pendapat para ahli, ketentuan perundang-undangan maupun beberapa literatur lainnya.

Istilah teror berasal dari bahwa Latin yaitu "terrorem" yang memiliki arti rasa takut yang luar biasa dan dalam kata kerja disebut "terrere" berarti membuat takut atau menakut-nakuti (Petrus Reinhard Golose 2009: 1). Pengertian teror menurut Adjie S. (2005: 11), adalah bentuk-bentuk kegiatan dalam rangka pelaksanaan terorisme melalui penggunaan/cara ancaman, pemerasan, agitasi, fitnah, pengeboman, penghancuran/perusakan, penculikan, intimidasi, perkosaan dan pembunuhan. Sedangkan teroris adalah pelaku atau pelaksana bentuk-bentuk terorisme, baik oleh individu, golongan ataupun kelompok dengan cara tindak kekerasan sampai dengan pembunuhan, disertai berbagai penggunaan senjata, mulai dari sistem konvensional hingga moderen.

Ali Masyhar (2009: 43) mengatakan bahwa tidak ada keseragaman pengertian terorisme, tetapi terorisme mempunyai ciri dasar, antara lain: penggunaan atau ancaman kekerasan, ada unsur pendadakan/kejutan, direncana-kan dan dipersiapkan secara cermat dan matang, menimbulkan ketakutan yang meluas atau membuat kehancuran material atau perekonomian, mempunyai tujuan politik yang jauh lebih luas dari sasaran/korban langsungnya. Lebih lanjut Ali Masyhar (2009: 43) mengatakan bahwa terorisme merupakan penggunaan atau ancaman kekerasan yang bersifat mendadak, namun direncanakan dan dipersiapkan secara matang, sehingga menimbulkan ketakutan meluas atau membuat kehancuran material dan perekonomian, dengan tujuan/unsur politis yang jauh lebih luas dari sasaran (korban) langsungnya. Sejalan dengan pengertian ini, Pettiford dan Harding (2003) sebagaimana dikutip A.M. Hendro Proyono (2009: 41) menjelas- 
kan bahwa karakteristik terorisme membutuhkan suatu perencanaan yang matang dan terperinci, kebiasaan-kebiasaan dan gerakan-gerakan sasaran (objek) diamati dengan cermat, teknik operasional persenjataan dan bom harus dikuasai penuh oleh pelaku, transportasi harus siap dan rumah yang aman (safe hause) harus disediakan.

Secara terminologi, terorisme dapat dipisahkan menjadi tiga suku kata yang memiliki makna berbeda antara satu sama lain. Kata dasar terorisme adalah teror, dalam bahasa Inggris disebut dengan kata terror, yakni keganasan, kekalutan yang disebabkan oleh beberapa orang/golongan yang melakukan tindakan-tindakan biadab (Simorangkir, dkk 2002: 162). Dalam kamus lain disebutkan bahwa teror adalah perbuatan, pemerintahan dan sebagainya yang sewenang-wenang, bengis dan sebagainya (Ali 2009: 561). Kata yang kedua adalah teroris, dalam bahasa Inggris disebut dengan kata terrorist yang berarti orang yang melakukan terorisme. Sedangkan kata yang ketiga adalah terorisme yang berarti penggunaan kekerasan, kebiadaban, keganasan yang dilakukan oleh orang, atau golongan orang untuk menimbulkan ketakutan orang lain demi mencapai tujuan, misalnya, tujuan politik (Hamzah 2009: 161-162).

Menurut Kaligis (2003: 6), kata teror berasal dari Bahasa Latin yang disebut dengan kata "terrere" yang dalam Bahasa Inggris diterjemahkan dalam perkataan "to fright", yang dalam Bahasa Indonesia berarti menakutkan atau mengerikan. Menurut Kamus Webster's New School and Office Dictionary, sebagaimana dikutip Mardenis (2011: 85) disebutkan bahwa teror sebagai kata benda berarti extreme afaer (ketakutan yang amat sangat), one who excites extreme afaer (seorang yang gelisah dalam ketakutan yang amat sangat), the ability to cause such afaer (kemampuan menimbulkan ketakutan).

Sesuai dengan istilah yang berlaku umum, dapat dikemukakan pengertian terorisme, sebagai berikut:

a. Ayatullah Sheikh Muhammad Al Taskhiri yang dimuat dalam Media (2003: 42) dikatakan bahwa terorism is an act carried out to achive on in human and corrupt objective and invoving thereat to scurity of mankind, and violation of right acknowledge by relegion and mankind (terorisme adalah suatu tindakan 
dilakukan untuk mencapai tujuan sekelompok manusia yang korup dan karenanya melibatkan keamanan umat manusia, dan pelanggaran hak diakui oleh agama dan umat manusia).

b. Moch Faisal Salam (2005: 3), menyatakan bahwa terrorism is the unlawful use of force or violence against human or property to intimidate or coerce a government, civilian populations, or any segment threat, in furtherance of politic or social objective (terorisme adalah segala tindakan yang melanggar hukum dengan cara pemaksaan, kekerasan atau pengintimidasian hak milik dengan memeras baik itu terhadap pemerintah, warga sipil atau segala bentuk ancaman sebagai kelanjutan dari tujuan politik dan sosial).

Dalam UU Terorisme tidak ada satu pasal pun yang menjelaskan pengertian atau defenisi terorisme, tetapi dalam Penjelasan Bagian Umum Paragraf Ketiga memuat kalimat yang disebutkan bahwa terorisme merupakan kejahatan terhadap kemanusiaan dan peradaban serta merupakan salah satu ancaman serius terhadap kedaulatan setiap negara karena terorisme sudah merupakan kejahatan yang bersifat internasional yang menimbulkan bahaya terhadap keamanan, perdamaian dunia serta merugikan kesejahteraan masyarakat sehingga perlu dilakukan pemberantasan secara berencana dan berkesinambungan sehingga hak asasi orang banyak dapat dilindungi dan dijunjung tinggi.

Berdasarkan uraian di atas, menurut Asmadi (2013: 126), dikatakan terorisme oleh pembuat undang-undang dalam uraian Penjelasan Pertimbangan UU Terorisme sedikitnya mengandung pengertian: (a) terorisme merupakan kejahatan terhadap kemanusiaan dan peradaban; (b) terorisme merupakan salah satu ancaman serius terhadap kedaulatan setiap negara; dan (c) terorisme merupakan kejahatan yang bersifat internasional yang menimbulkan bahaya terhadap keamanan, perdamaian dunia serta merugikan kesejahteraan masyarakat.

Menurut Moch. Faisal Salam (2005: 3), dikatakan bahwa tindakan kekerasan (terrorism) diartikan sebagai cara bagi kelompok tertentu untuk mencapai tujuan dan selanjutnya diartikan sebagai:

a. cara kelompok miskin untuk meminta perhatian kelompok kaya;

b. cara kelompok yang dimarjinalkan terhadap kelompok yang diuntungkan; 
c. cara kelompok yang tertekan terhadap kelompok yang arogan; serta

d. cara kelompok yang dimusuhi, diblokade, diembargo, diperlakukan tidak adil dan sebagainya.

Dalam Encyclopedia of Britanica Terorisme yang dijelaskan, bahwa: "Terrorism is the systematic use of violence to create a general climate of fear in a population and thereby to bring about a particular political objective" (terorisme adalah penggunaan kekerasan secara sistematis untuk menciptakan sebuah rasa takut secara meluas dalam suatu populasi sebagai sarana untuk mencapai tujuan politik tertentu). Berdasarkan definisi tersebut, maka terorisme masih erat kaitannya dengan kondisi kekerasan yang dimanfaatkan untuk kepentingan pencapaian tujuan politik tertentu.

Ezzath E. Fattah dalam Petrus Reinhard Golose (2009: 2), dikatakan bahwa: "terrorism comes from terror, which come Latin terre, meaning to frighten. Originally, the word terroe was used designate a mode governing, and word terrorism was emmpleyed to describe the systematic use of terror, especially by governed into submission" (terorisme berasal dari kata teror, dalam bahasa latinnya terre yang artinya menakut-nakuti. Sebenarnya kata terre digunakan untuk menentukan suatu cara mengatur dan kata terrorism digunakan untuk menggambarkan penggunaan teror secara sistematis, ter-utama dengan tindakan mengatur agar menyerah). Petrus Reinhard Golose (2009: 6), mengatakan bahwa:

terorisme adalah setiap tindakan yang melawan hukum dengan cara menebarkan teror secara meluas kepada masyarakat, dengan ancaman atau cara kekerasan, baik diorganisir maupun tidak, serta menimbulkan akibat berupa penderitaan fisik dan/atau psikologis dalam waktu ber-kepanjangan sehingga dikategorikan sebagai tindak kejahatan yang luar biasa (extra ordinary crime) dan kejahatan terhadap kemanusiaan (crime against humanity).

Dalam Pasal 6 Perpu No. 1 Tahun 2002 disebutkan bahwa setiap orang yang dengan sengaja menggunakan kekerasan atau ancaman kekerasan menimbulkan suasana teror atau rasa takut terhadap orang secara meluas atau menimbulkan korban bersifat massal, dengan cara merampas kemerdekaan atau hilangnya nyawa dan harta benda orang lain atau mengakibatkan kerusakan atau kehancuran terhadap obyek-obyek vital yang strategis atau lingkungan hidup atau 
fasilitas publik atau fasilitas internasional, dipidana dengan pidana mati atau penjara seumur hidup atau pidana penjara paling singkat 4 (empat) tahun dan paling lama 20 (dua puluh) tahun. Dalam penjelasan Pasal 6 disebutkan bahwa yang dimaksud dengan kerusakan atau kehancuran lingkungan hidup adalah tercemarnya atau rusaknya kesatuan ruang dengan semua benda, daya, keadaan dan makhluk hidup termasuk manusia dan perilakunya, yang mempengaruhi kelangsungan perikehidupan dan kesejahteraan manusia serta makhluk lainnya. Termasuk merusak atau menghancurkan adalah dengan sengaja melepaskan atau membuang zat, energi, dan/atau komponen lain yang berbahaya atau beracun ke dalam tanah, udara atau air permukaan yang membahayakan terhadap orang atau barang. Selanjutnya dalam Pasal 7 Perpu No. 1 Tahun 2002 disebutkan bahwa setiap orang yang dengan sengaja menggunakan kekerasan atau ancaman kekerasan bermaksud untuk menimbulkan suasana teror atau rasa takut terhadap orang secara meluas atau menimbulkan korban yang bersifat massal dengan cara merampas kemerdekaan atau hilangnya nyawa atau harta benda orang lain atau untuk menimbulkan kerusakan atau kehancuran terhadap obyek-obyek vital yang strategis atau lingkungan hidup atau fasilitas publik atau fasilitas internasional, dipidana dengan pidana penjara paling lama seumur hidup.

Terorisme dapat dikatakan sebagai kejahatan internasional, dan untuk dapat memahami kejahatan terorisme sebagai kejahatan internasional atau tidak, harus dipahami terlebih dahulu apa yang dimaksud dengan kejahatan internasional (internasional crime). Terhadap kejahatan internasional, Tien Saefullah merinci unsur-unsur yang terkandung dalam kejahatan internasional, yaitu: (a) perbuatan itu secara universal, dalam artian semua negara harus mengkualifikasikan sebagai tindak pidana; (b) pelakunya merupakan enemy of mankind (musuh umat manusia) dan tindakannya bertentangan dengan kepentingan umat manusia; dan (c) menyerahkan pelaku tindak pidana tersebut untuk diadili dengan prinsip universal (Arief Setiawan. http://www.ashlf.com. diakses tanggal 18 Maret 2016).

Cherief Bassiouni memberikan pengertian atas kejahatan internasional yaitu sebagai berikut: "internastional crimes is any conduct which is designated as a crime in a multilateral convention will a significant number of state parties to 
it, provided the instrument contains one of ten penal characteristic". Dengan demikian, untuk menentukan adanya kejahatan internasional tidak cukup hanya dengan mengetahui kejahatan tersebut sudah diatur dalam konvensi yang bersifat multilateral, tetapi juga harus memenuhi salah satu dari sepuluh karakteristik. Dari kriteria tersebut Bassiouni menetapkan 22 macam kejahatan yang dapat dipandang sebagai kejahatan internasional, terorisme tidak termasuk di dalamnya (Arief Setiawan. http://www.ashlf.com. diakses tanggal 18 Maret 2016).

Demikian juga jika dicermati dari konvensi internasional sejak tahun 1937 sampai tahun 1999 dan beberapa Resolusi Dewan Keamanan PBB bahwa penetapan terorisme sebagai kejahatan sebatas kejahatan yang mengancam perdamaian dan keamanan umat manusia (threaten to the peace and security of mankind) sesuai dengan Chapter VII Piagam PBB, dengan implikasi hukum adanya kewajiban setiap negara untuk menangkap, menuntut, menghukum atau mengekstradisi pelaku teroris. Hal yang sama jika mem-perhatikan Statuta Roma tentang Internasional Criminal Court (ICC) yang ditandatangani oleh 120 negara pada tanggal 17 juli 1998. ICC dibentuk sebagai pengadilan internasional permanen yang khusus mengadili para pelaku yang didakwa melakukan kejahatan internasional. Pasal 5 sampai dengan Pasal 8 yang mengatur tentang kewenangan mengadili atau yudiksi ICC, yang di dalamnya tidak ada mencantumkan terorisme sebagai kejahatan yang dapat diadilinya.

Secara eksplisit status hukum terorisme belum merupakan kejahatan internasional, tetapi melalui resolusi yang dikeluarkan Dewan Keamanan pasca gedung WTC pada tahun 2001 menyerukan agar persoalan terorisme ini mendapatkan perhatian dan kerja sama sepenuhnya dari negara-negara. Ini berarti pemberantasan dan pencegahan kejahatan terorisme tidak saja menjadi korban atau yang terancam saja tetapi lebih menjadi tanggung jawab kolektif dari masyarakat internasional.

Cherief Bassouni dalam Romli Atmasasmita (2000: 46), mengemukakan bahwa kejahatan internasional meliputi:

a. unsur internasional, termasuk ke dalam unsur ini adalah:

1) ancaman secara langsung atas perdamaian dan keamanan di dunia; 
2) ancaman secara tidak langsung atas atas perdamaian dan keamanan di dunia; dan

3) menggoyahkan perasaan kemanusian

b. unsur transnasional, termasuk ke dalam unsur ini adalah:

1) tindakan yang memiliki dampak terhadap lebih dari satu negara.

2) tindakan yang melibatkan atau memberikan dampak terhadap negara dari lebih satu negara.

3) sarana dan prasarana serta metode yang dipergunakan telah melampaui batas-batas teritorial suatu negara.

c. unsur necessity, termasuk ke dalam unsur ini adalah, kebutuhan akan kerja sama antar negara-negara untuk melakukan penanggulangan.

\section{Pembiayaan atau pendanaan terorisme}

Pembiayaan berasal dari kata dasar biaya, di dalam Kamus Besar Bahasa Indonesia berarti uang yang dikeluarkan untuk mengadakan (mendirikan, melakukan dan sebagainya) sesuatu; belanja; pengeluaran (Departemen Pendidikan Nasional 2008: 186). Pembiayaan sendiri dalam Kamus Besar Bahasa Indonesia berarti segala sesuatu yang berhubungan dengan biaya (Departemen Pendidikan Nasional 2008: 187).

Kamus Besar Bahasa Indonesia menyebutkan biaya tersebut memiliki arti yang berhubungan dengan dana, dimana dana dimaksud berarti uang yang disediakan untuk suatu keperluan (Departemen Pendidikan Nasional 2008: 291), sedangkan pendanaan berarti penyediaan dana (Departemen Pendidikan Nasional 2008: 292). Pendanaan sebagaimana maksud dalam penulisan ini berkaitan erat dengan International Convention for the Suppression of the Financing of Terrorism Tahun 1999 yang kemudian diratifikasi oleh Pemerintah Republik Indonesia melalui UU No. 6 Tahun 2006 tentang Pengesahan International Convention for the Suppression of the Financing of Terrorism, 1999 (Konvensi Internasional Pemberantasan Pendanaan Terorisme Tahun 1999) yang disahkan pada Tanggal 5 April 2006.

Penanganan pencegahan pendanaan terorisme ini kembali dikuatkan melalui pengesahan UU No. 9 Tahun 2013, dimana dalam Pasal 1 Angka 1 
disebutkan defenisi dari pendanaan terorisme dan selanjutnya berdasarkan ketentuan Pasal 1 Angka 7 UU No. 9 Tahun 2013, maka dana yang dimaksud adalah semua aset atau benda bergerak atau tidak bergerak, baik yang berwujud maupun yang tidak berwujud, yang diperoleh dengan cara apa pun dan dalam bentuk apa pun, termasuk dalam format digital atau elektronik, alat bukti kepemilikan, atau keterkaitan dengan semua aset atau benda tersebut, termasuk tetapi tidak terbatas pada kredit bank, cek perjalanan, cek yang dikeluarkan oleh bank, perintah pengiriman uang, saham, sekuritas, obligasi, bank draf dan surat pengakuan utang.

\section{Peranan perbankan dalam pencegahan pendanaan terorisme}

Rumusan delik dari tindak pidana terorisme dalam ketentuan hukum positif di Indonesia dapat dilihat dalam UU Terorisme, tetapi tidak satupun pasal yang menjelaskan kata "isme" sehingga pengertian terorisme masih bernilai abstrak. Kondisi tersebut di atas, tepatlah asumsi yang menyatakan pengertian terorisme tersebut masih dalam perdebatan (Anwar dan Adang 2010: 420). Tindak pidana terorisme menjadikan korban yang tidak pandang bulu, tetapi menurut . Purwanto (2010: 71), dijelaskan bahwa dibalik aksi teror yang dilakukan pelakunya merupakan bentuk kekerasan politik yang dapat dibedakan menjadi 2 (dua) aspek yakni:

a. Korban adalah yang kebetulan ada di tempat kejadian, pengunjung, tamu hotel, satpam, penjual rokok, tukang parkir, jemaah rumah ibadah, anak-anak, sopir, dan mereka yang sebenarnya terpaksa atau sengaja dikorbankan untuk tujuan sosial atau politik tertentu; dan

b. Terkait pesan yang ingin disampaikan kepada masyarakat atau publik politik yang dimanipulasi atau diprovokasi untuk aneka tujuan sosial dan politik tertentu.

Secara rasional, tindakan kekerasan bukan tujuan akhir tetapi merupakan cara yang dipandang paling efektif untuk aneka capaian lain yang lebih substansial. Aksi teror, umumnya disertai pernyataan teroris sebagai pihak yang bertanggung jawab berikut tuntutannya. Celakanya hal ini tidak muncul dalam berbagai peledakan bom di Indonesia yang jika pelakunya tertangkap memilih 
bersikap anonim (Purwanto 2010: 71). Salah satu masalah yang kerap dihadapi oleh instansi-instansi pemerintah Indonesia dalam menangani masalah terorisme adalah belum terciptanya kordinasi yang baik antar lembaga pemerintah terkait (Purwanto 2007: 115). Selain itu, terorisme tidak akan selesai dengan cara refresif yang berarti terorisme tidak dapat diatasi dengan kekerasan tetapi lebih kepada penyelesaian akar masalah (Purwanto 2004: 40).

Tindakan refresif dikenal dengan pro-kontranya, artinya perburuan teroris oleh aparat kepolisian menimbulkan kontroversi karena dinilai melanggar HAM dan pro kepentingan asing. Hal ini menunjukkan upaya pemberantasan terorisme bukan karena pesanan tertentu tapi demi semata-mata demi keamanan dan kesinambungan pembangunan nasional (Mardenis 2011: 144). Pembangunan nasional khususnya di bidang hukum melalui Program Legislasi Nasional (Prolegnas) telah banyak menerbitkan aturan perundang-undangan yang mengatur tentang pemberantasan terorisme, antara lain:

a. Undang-undang Nomor 15 Tahun 2003 tentang Penetapan Peraturan Pemerintah Pengganti Undang-undang Nomor 1 Tahun 2002 tentang Pemberantasan Tindak Pidana Terorisme Menjadi Undang-undang;

b. Undang-undang Nomor 8 Tahun 2010 tentang Pencegahan dan Pemberantasan Tindak Pidana Pencucian Uang;

c. Undang-undang Nomor 9 Tahun 2013 tentang Pencegahan dan Pemberantasan Tindak Pidana Pendanaan Terorisme;

d. Peraturan Pemerintah Nomor 46 Tahun 2010 tentang Badan Nasional Penanggulangan Terorisme (BNPT);

e. Peraturan Bank Indonesia Nomor 11/28/PBI/2009 tentang Penerapan Program Anti Pencucian Uang dan Pencegahan Pendanaan Terorisme bagi Bank Umum; dan

f. Keputusan Kepala Pusat Pelaporan dan Analisis Transaksi Keuangan Nomor KEP-13/1.02.2/PPATK/02/08 tentang Pedoman Identifikasi Transaksi Keuangan Mencurigakan Terkait Pendanaan Terorisme bagi Penyedia Jasa Keuangan; 
g. Surat Keputusan Bersama Jaksa Agung Republik Indonesia, Kepala Kepolisian Negara Republik Indonesia dan Gubernur Bank Indonesia Nomor KEP-902/A/J.A/12/2004, Nomor Polisi: SKep/924/XII/2004, Nomor 6/91/ KEP.GBI/2004 tentang Kerjasama Penanganan Tindak Pidana di Bidang Perbankan.

Selain berbagai peraturan perundang-undangan di atas, masih banyak lagi peraturan lain yang berkenaan dengan upaya penanganan terorisme ini. Kebanyakan peraturan tersebut, mengatur tentang perbankan yang berkaitan dengan upaya pencegahan tindak pidana terorisme. Pendanaan terorisme mutlak untuk diperangi, mengingat dampak yang ditimbulkannya sungguh luar biasa. Kegiatan terorisme tanpa unsur pendanaan akan tumpul, sehingga hukum perbankan dalam pemberantasan tindak pidana terorisme mutlak diciptakan secara lebih seksama sehingga mampu memberikan inspirasi agar bank berinisiatif melakukan deteksi dini dan Bank Indonesia harus memperkuat unit penyidik perbankan sepanjang ada tindak pidana perbankan (Purwanto 2010: 28).

Bank berarti badan usaha di bidang keuangan yang menarik dan mengeluarkan uang dalam masyarakat, terutama memberikan kredit dan jasa dalam lalu lintas pembayaran dan peredaran uang, sehingga perkataan perbankan berarti segala sesuatu mengenai bank (Departemen Pendidikan Nasional 2008: 135-136), sedangkan dalam UU Perbankan, menyebutkan bahwa bank adalah badan usaha yang menghimpun dana dari masyarakat dalam bentuk simpanan dan menyalurkannya kepada masyarakat dalam bentuk kredit dan atau bentuk-bentuk lainnya dalam rangka meningkatkan taraf hidup rakyat banyak.

Berdasarkan defenisi di atas, terdapat peran yang dilakukan badan usaha tersebut untuk menyerap dana dari dan menyalurkan kembali kepada masyarakat. Istilah kata peran berarti "perangkat tingkah yang diharapkan dimiliki oleh orang yang berkedudukan dalam masyarakat" (Departemen Pendidikan Nasional 2008: 1051). Kata peran ini menunjukkan adanya kedudukan bank yang diberikan wewenang oleh negara melalui berbagai peraturan perundang-undangan untuk menampung, menggunakan serta menyalurkan dana atau uang dari dan kepada masyarakat. Apalagi dalam Pasal 3 UU Perbankan disebutkan fungsi utama 
perbankan Indonesia adalah sebagai penghimpun dan penyalur dana masyarakat. Selanjutnya, dalam Pasal 4 UU Perbankan disebutkan bahwa tujuan dari Perbankan Indonesia adalah menunjang pelaksanaan pembangunan nasional dalam rangka meningkatkan pemerataan, pertumbuhan ekonomi dan stabilitas nasional kearah peningkatan kesejahteraan rakyat banyak.

Bank Indonesia dalam menerapkan Program Anti Pencucian Uang dan Pencegahan Pendanaan Terorisme bagi Bank Umum mempertimbangkan adanya tindak pidana pencucian uang dan pendanaan terorisme yang memanfaatkan lembaga keuangan. Dengan demikian diperlukan kerjasama dan perhatian dari berbagai pihak dalam pencegahan dan pemberantasan tindak pidana tersebut. Selanjutnya, tidak dapat dipungkiri bahwa perkembangan produk, aktifitas dan teknologi informasi bank yang semakin kompleks meningkatkan peluang bagi para pelaku kejahatan untuk menyalahgunakan sarana dan produk perbankan dalam membantu tindak kejahatannya.

Pendanaan terorisme adalah penggunaan harta kekayaan secara langsung atau tidak langsung untuk kegiatan terorisme sebagaimana dimaksud dalam UU Pencucian Uang. Berdasarkan defenisi di atas, terdapat tiga instrumen tindak pidana yang mencakup pendanaan terorisme yakni:

a. Tindak pidana pencucian uang

Tindak Pidana Pencucian Uang (money laundering) secara populer dapat dijelaskan sebagai aktivitas memindahkan, menggunakan atau melakukan perbuatan lainnya atas hasil dari tindak pidana yang kerap dilakukan oleh organized crime maupun individu yang melakukan tindakan korupsi, perdagangan narkotika dan tindak pidana lainnya dengan tujuan menyembunyikan atau mengaburkan asal-usul uang yang berasal dari hasil tindak pidana tersebut sehingga dapat digunakan seolah-olah sebagai uang yang sah tanpa terdeteksi bahwa uang tersebut berasal dari kegiatan illegal (Husein, 2003:26). Black's Law Dictionary memberikan batasan tentang pencucian uang sebagai Term used to describe investment or other transfer of money flowing from racketeering, drug transaction and other illegal sources into legitimate channels so that its original source cannot be traced (Sitompul 2007: 9). 
Pemberlakuan ketentuan pemberantasan tindak pidana pencucian uang telah dilaksanakan di Indonesia sejak lahirnya UU No. 15 Tahun 2002 yang di dalamnya belum memuat ketentuan tentang financing of terrorisme atau terrorist financing. Terdapat pengkriminalisasian terorisme yang ditunjukkan pada Pasal 2 yang menentukan terorisme sebagai tindak pidana asal (predicate crime atau underlying crime) atau yang menjadi harta kekayaan hasil tindak pidana dan merupakan objek pencucian uang. Berdasarkan adanya ketentuan Pasal 2 UU tersebut bertujuan:

1) Agar Pemerintah Republik Indonesia menunjukkan pada dunia internasional bahwa Indonesia ikut dalam gerakan anti-terorisme; dan

2) Untuk mengantisipasi keluarnya UU Terorisme yang akan mengkriminalisasi terorisme sebagai tindak pidana.

UU No. 15 Tahun 2002 tersebut kemudian mengalami pembaharuan, terakhir diubah berdasarkan UU Nomor 8 Tahun 2010. Di dalam UU tersebut telah menambahkan satu pasal baru yakni Pasal 2 Ayat (2) yang mengatur tentang harta kekayaan yang diketahui atau patut diduga akan digunakan dan/atau digunakan secara langsung atau tidak langsung untuk kegiatan terorisme, organisasi teroris, atau teroris perseorangan.

b. Tindak pidana terorisme

Berdasarkan Penjelasan Umum UU Terorisme menyebutkan bahwa Terorisme merupakan kejahatan terhadap kemanusiaan dan peradaban serta merupakan salah satu ancaman serius terhadap kedaulatan setiap negara karena terorisme sudah merupakan kejahatan yang bersifat internasional yang menimbulkan bahaya terhadap keamanan, perdamaian dunia serta merugikan kesejahteraan masyarakat sehingga perlu dilakukan pemberantasan secara berencana dan berkesinambungan sehingga hak asasi orang banyak dapat dilindungi dan dijunjung tinggi.

Kriminalisasi pendanaan terorisme dalam UU Terorisme dinyatakan dalam Pasal 11, bahwa dipidana dengan pidana penjara paling singkat 3 (tiga) tahun dan paling lama 15 (lima belas) tahun, setiap orang yang dengan sengaja menyediakan atau mengumpulkan dana dengan tujuan akan digunakan atau patut diketahuinya 
akan digunakan sebagian atau seluruhnya untuk melakukan tindak pidana terorisme sebagaimana dimaksud dalam Pasal 6, Pasal 7, Pasal 8, Pasal 9 dan Pasal 10.

Selain itu, Pasal 13 UU Terorisme terdapat perbuatan yang dikriminalisasi lainnya sebagai pembantuan terhadap pelaku tindak pidana terorisme, yakni:

1) Setiap orang yang menyediakan atau mengumpulkan harta kekayaan, dimana harta kekayaan disini didefinisikan secara lebih luas, untuk mendukung aksi terorisme yang terkait dengan bahan-bahan nuklir, senjata kimia dan biologis, dan lain-lain;

2) Setiap orang yang memberikan bantuan atau kemudahan terhadap pelaku tindak pidana terorisme, antara lain dengan memberikan atau meminjamkan uang atau barang atau harta kekayaan lainnya kepada pelaku tindak pidana terorisme.

c. Tindak pidana perbankan

Terdapat dua istilah yang seringkali dipakai secara bergantian walaupun maksud dan ruang lingkupnya bisa berbeda. Pertama, adalah "Tindak Pidana Perbankan" dan kedua, "Tindak Pidana di Bidang Perbankan". Yang pertama mengandung pengertian tindak pidana itu semata-mata dilakukan oleh bank atau orang bank, sedangkan yang kedua tampaknya lebih netral dan lebih luas karena dapat mencakup tindak pidana yang dilakukan oleh orang di luar dan di dalam bank atau keduanya (Reksodiputro 1994: 74).

Istilah "tindak pidana di bidang perbankan" dimaksudkan untuk menampung segala jenis perbuatan melanggar hukum yang berhubungan dengan kegiatan-kegiatan dalam menjalankan usaha bank. Tidak ada pengertian formal dari tindak pidana di bidang perbankan. Ada yang mendefinisikan secara popular, bahwa tindak pidana perbankan adalah tindak pidana yang menjadikan bank sebagai sarana (crimes through the bank) dan crimes against the bank atau sasaran tindak pidana itu (Sitompul 2007: 3-4). Sesuai dengan UU Perbankan, maka terdapat tiga belas macam tindak pidana yang dapat digolongkan ke dalam empat macam, yakni: 
1) Tindak pidana yang berkaitan dengan perizinan;

2) Tindak Pidana yang berkaitan dengan rahasia bank;

3) Tindak pidana yang berkaitan dengan pengawasan dan pembinaan bank; dan

4) Tindak pidana yang berkaitan dengan usaha bank.

Berdasarkan keempat bentuk tindak pidana perbankan di atas, bentuk yang berkaitan dengan tindak pidana pencucian uang atau potensi penggunaan pendanaan bagi terorisme adalah bentuk yang terakhir yakni yang berkaitan dengan usaha bank. Tindak pidana ini ditujukan kepada "orang dalam" yakni pihak yang menyelenggarakan perbankan antara lain Komisaris, anggota dewan komisaris, direksi atau pegawai bank. Kategori tindak pidana perbankan yang berkaitan dengan usaha bank di antaranya:

1) membuat atau menyebabkan adanya pencatatan palsu dalam pembukuan atau dalam laporan, maupun dalam dokumen atau laporan kegiatan usaha, laporan transaksi atau rekening suatu bank;

2) menghilangkan atau tidak memasukkan atau menyebabkan tidak dilakukannya pencatatan dalam pembukuan atau dalam laporan, maupun dalam dokumen atau laporan kegiatan usaha, laporan transaksi atau rekening suatu bank;

3) mengubah, mengaburkan, menyembunyikan, menghapus, atau menghilangkan adanya suatu pencatatan dalam pembukuan atau dalam laporan, maupun dalam dokumen atau laporan kegiatan usaha laporan transaksi atau rekening suatu bank, atau dengan sengaja mengubah, mengaburkan, menghilangkan, menyembunyikan atau merusak catatan pembukuan tersebut,

4) meminta atau menerima, mengizinkan atau menyetujui untuk menerima suatu imbalan, komisi, uang tambahan, pelayanan, uang atau barang berharga, untuk keuntungan pribadinya atau untuk keuntungan keluarganya, dalam rangka mendapatkan atau berusaha mendapatkan bagi orang lain dalam memperoleh uang muka, bank garansi, atau fasilitas kredit dari bank, atau dalam rangka pembelian atau pendiskontoan oleh bank atas surat-surat wesel, surat promes, cek, dan kertas dagang atau bukti kewajiban lainya, ataupun dalam rangka memberikan persetujuan bagi orang lain untuk melaksanakan penarikan dana yang melebihi batas kreditnya pada bank; 
5) tidak melaksanakan langkah-langkah yang diperlukan untuk memastikan ketaatan bank terhadap ketentuan dalam undang-undang ini dan ketentuan peraturan perundang-undangan lainya yang berlaku bagi bank.

Terkait pengimplementasian peranan perbankan dalam pencegahan pendanaan terorisme ada dua faktor penting yang perlu menjadi fokus perhatian, yaitu:

a. Faktor yuridis

Pentingnya perang melawan pendanaan terorisme tumbuh seiring dengan maraknya aksi-aksi terorisme di seluruh dunia. Meskipun tindakan-tindakan yang untuk mencegah pendanaan terorisme banyak persamaannya dengan yang digunakan untuk pemberantasan pencucian uang namun perlu diingat bahwa pendanaan terorisme dapat pula berasal dari sumber yang halal. Dengan demikian sumber pendanaan terorisme dapat diperoleh secara halal maupun secara tidak halal, sedangkan sumber uang yang terkena pencucian senantiasa merupakan hasil tindak pidana (Purwanto 2010: 110).

Dunia internasional dalam menghadapi dampak pendanaan terorisme ini telah meregulasi International Convention for the Suppression of the Financing of Terrorism, Tahun 1999 (selanjutnya disingkat SFT). Konvensi Internasional tentang Pemberantasan Terhadap Pendanaan Terorisme dan Pemerintah Republik Indonesia ikut menandatangani konvensi ini pada Tanggal 24 September 2001 dan telah meratifikasinya melalui melalui UU No. 6 Tahun 2006. Ratifikasi konvensi tersebut sangat terkait dengan Financial Action Task Force Special Recommendations on Terorism Financing (selanjutnya disingkat FATF), yang ditujukan menghalangi akses bagi para teroris dan pendukungnya untuk masuk ke sistem keuangan internasional.

Indonesia sebagai negara yang rawan terhadap ancaman terorisme telah melakukan upaya dalam memenuhi rekomendasi FATF tersebut. Selain meratifikasi SFT, terdapat regulasi yang mengatur secara khusus tentang pencegahan pendanaan terorisme ini sebagaimana dikemukakan sebelumnya. Lebih spesialis, terdapat Peraturan Bank Indonesia Nomor 11/28/PBI/2009 tentang Penerapan Program Anti Pencucian Uang dan Pencegahan Pendanaan 
Terorisme Bagi Bank Umum (selanjutnya disingkat PBI 11/2009). Lahirnya PBI 11/2009 dilatarbelakangi keadaan sebagai berikut:

1) bahwa dengan semakin kompleksnya produk, aktivitas, dan teknologi informasi bank maka risiko pemanfaatan bank dalam pencucian uang dan pendanaan teroris semakin tinggi;

2) bahwa peningkatan risiko yang dihadapi bank perlu diimbangi dengan peningkatan kualitas penerapan manajemen risiko yang terkait dengan program anti pencucian uang dan pencegahan pendanaan terorisme;

3) bahwa penerapan manajemen risiko yang terkait dengan program anti pencucian uang dan pencegahan pendanaan terorisme perlu mengacu pada prinsip-prinsip umum yang berlaku secara internasional;

4) bahwa ketentuan tentang Penerapan Prinsip Mengenal Nasabah (Know Your Customer Principles) yang selama ini berlaku, perlu disempurnakan.

Bank sebagai penyedia layanan lalu lintas keuangan memiliki kewajiban untuk menerapkan program Anti Pencucian Uang dan Pencegahan pendanaan terorisme dengan berpedoman kepada PBI 11/2009. Beraneka ragam kewajiban yang harus dipenuhi oleh bank dalam rangka memenuhi standar menerapkan program anti pencucian uang dan pencegahan pendanaan terorisme. Di antara kewajiban tersebut, bank harus memiliki kebijakan dan prosedur tertulis yang paling kurang mencakup: permintaan informasi dan dokumen; Beneficial Owner; verifikasi dokumen; CDD yang lebih sederhana; penutupan hubungan dan penolakan transaksi; ketentuan mengenai area berisiko tinggi dan PEP; pelaksanaan CDD oleh pihak ketiga; pengkinian dan pemantauan; Cross Border Correspondent Banking; transfer dana; dan penatausahaan dokumen.

Berdasarkan Penjelasan Umum dari UU No. 8 Tahun 2010, disebutkan penelusuran harta kekayaan hasil tindak pidana pada umumnya dilakukan oleh lembaga keuangan melalui mekanisme yang diatur dalam peraturan perundangundangan. Lembaga keuangan memiliki peranan penting khususnya dalam menerapkan prinsip mengenali Pengguna Jasa dan melaporkan Transaksi tertentu kepada otoritas (financial intelligence unit) sebagai bahan analisis dan untuk selanjutnya disampaikan kepada penyidik. 
Lembaga keuangan tidak hanya berperan dalam membantu penegakan hukum, tetapi juga menjaga dirinya dari berbagai risiko, yaitu risiko operasional, hukum, terkonsentrasinya Transaksi, dan reputasi karena tidak lagi digunakan sebagai sarana dan sasaran oleh pelaku tindak pidana untuk mencuci uang hasil tindak pidana. Dengan pengelolaan risiko yang baik, lembaga keuangan akan mampu melaksanakan fungsinya secara optimal sehingga pada gilirannya sistem keuangan menjadi lebih stabil dan terpercaya.

Faktor yuridis sebagai faktor pendukung pelaksanaan dari penerapan program anti pencucian uang dan pencegahan tindak pidana terorisme yang sangat penting adalah adanya sanksi atas pelanggaran yang dilakukan perbankan, yakni:

1) Bank diberi sanksi kewajiban membayar:

a) Rp 1.000.000,00 (satu juta rupiah) per hari keterlambatan per laporan apabila terlambat memberikan laporan rencana dan realisasi pengkinian data atau terlambat memberikan laporan Transaksi Keuangan Mencurigakan, laporan transaksi keuangan tunai, dan laporan lain sebagaimana diatur dalam Undang-undang tentang Tindak Pidana Pencucian Uang.

b) Rp 50.000.000,00 (lima puluh juta rupiah) dan teguran tertulis apabila belum menyampaikan pedoman atau laporan Transaksi Keuangan Mencurigakan dalam waktu lebih 1 (satu) bulan sejak batas akhir waktu penyampaian;

c) paling banyak sebesar Rp 100.000.000,00 (seratus juta rupiah) apabila bank tidak melaksanakan komitmen penyelesaian hasil temuan pemeriksaan Bank Indonesia dalam kurun waktu waktu 2 (dua) kali pemeriksaan atau tidak melaksanakan komitmen yang telah dituangkan dalam rencana kegiatan pengkinian data.

2) Sanksi lain yang terkait dengan Undang-undang Perbankan dan Undangundang Perbankan Syariah, antara lain berupa: teguran tertulis; penurunan tingkat kesehatan Bank; pembekuan kegiatan usaha tertentu; pencantuman anggota pengurus, pegawai Bank, dan/atau pemegang saham dalam daftar pihak-pihak yang mendapat predikat tidak lulus dalam penilaian kemampuan dan kepatutan atau dalam catatan administrasi Bank Indonesia sebagaimana 
diatur dalam ketentuan Bank Indonesia yang berlaku; dan/atau pemberhentian pengurus Bank.

Berdasarkan UU No. 9 Tahun 2013 yang mengatur tentang kewenangan untuk mengawasi lembaga penyedia jasa keuangan yang sangat rentan terhadap kejahatan pendanaan terorisme. Pengawasan terhadap lembaga penyedia jasa keuangan harus menjadi perhatian serius untuk menghindarkan lembaga tersebut dari kejahatan terorisme. Pengawasan tersebut, antara lain:

1) Pengawasan kepatuhan PJK atas kewajiban pelaporan Transaksi Keuangan Mencurigakan Terkait Pendanaan Terorisme dilakukan oleh PPATK dan LPP yang berwenang.

2) Pengguna Jasa Keuangan yang melakukan Transaksi pengiriman uang melalui sistem transfer wajib memberikan identitas dan informasi yang benar mengenai pengirim asal, alamat pengirim asal, penerima kiriman, jumlah uang, jenis mata uang, tanggal pengiriman uang, sumber dana, dan informasi lain yang berdasarkan ketentuan peraturan perundang-undangan wajib diberikan ke PJK.

3) Pengguna jasa keuangan harus memberikan informasi yang jelas mengisi formulir yang disediakan oleh PJK dengan melampirkan dokumen pendukung.

4) Dalam hal Pengguna Jasa Keuangan tidak memberikan informasi yang diminta, PJK wajib menolak pengiriman uang melalui sistem transfer tersebut.

5) PJK pengirim wajib menyimpan semua informasi yang diperlukan untuk mengenali semua pengirim asal dan penerima kiriman paling singkat 5 (lima) tahun sejak berakhirnya Transaksi pengiriman uang melalui sistem transfer.

6) PJK yang tidak melakukan verifikasi data pengguna jasa keuangan akan dikenai sanksi sesuai dengan ketentuan peraturan perundang-undangan.

Selain pengawasan melalui transfer, penyedia jasa keuangan juga diawasi dari kegiatan pengiriman uang melalui sistem lain, yakni:

1) PJK yang menyelenggarakan kegiatan pengiriman uang melalui sistem lainnya wajib memperoleh izin dari dan/atau terdaftar di LPP. 
2) PJK yang menyelenggarakan kegiatan pengiriman uang melalui sistem lainnya wajib menyampaikan laporan tertulis mengenai penyelenggaraan kegiatan pengiriman uang ke LPP.

3) Dalam hal PJK tidak memenuhi kewajibannya, LPP berwenang mengenakan sanksi administratif. Terkait sanksi administratif dan tata cara penyampaian laporan penyelenggaraan kegiatan pengiriman uang diatur dalam peraturan LPP masing-masing.

Berdasarkan ketentuan Pasal 21 UU No. 9 Tahun 2013, maka pengawasan juga dilakukan terhadap pembawaan uang tunai dan instrumen pembayaran lain ke dalam atau ke luar daerah pabean Indonesia pengawasan ini dilakukan oleh Direktorat Jenderal Bea dan Cukai.

b. Faktor sosiologis

Faktor sosiologis dalam pencegahan pendanaan terorisme oleh perbankan didasari oleh adanya Resolusi Dewan Keamanan PBB Nomor 1267 tanggal 15 Oktober 1999. Resolusi ini telah diadopsi dalam Bab VII United Nations Charter. Inti dari Resolusi ini antara lain meminta setiap negara untuk melakukan "pembekuan seketika" terhadap dana dan aset keuangan lainnya atau sumber ekonomis dari individu dan entitas yang berkaitan dengan Al-Qaida, Usama bin Laden dan/atau Taliban. Karena itu perlu landasan hukum yang kuat sehingga memungkinkan Indonesia melaksanakan Resolusi DK PBB tersebut (Husein 2011. www.ppatk.go.id. diakses pada tanggal 10 Januari 2012).

Selain itu, industri keuangan telah pula menerapkan KYC/CDD antara dalam rangka pencegahan dan pemberantasan pendanaan terorisme sesuai ketentuan yang dikeluarkan regulator seperti PBI 11/2009. Berbagai pelaksanaan regulasi di atas bukan tanpa tujuan, artinya terdapat kajian sosiologis penerapan regulasi dimaksud, di antaranya:

1) untuk mengatasi loopholes yang ada dalam peraturan yang berkaitan dengan tindak pidana pendanaan terorisme sehingga menjamin kepastian hukum dan ketertiban dalam masyarakat;

2) untuk mengetahui dan mengatur prosedur dan mekanisme yang jelas upaya pencegahan dan pemberantasan tindak pidana terorisme melalui pendekatan 
follow the money namun tidak menghambat kegiatan pengelola jasa keuangan

(Husein 2011. www.ppatk.go.id. diakses pada tanggal 10 Januari 2012)

Menurut Paul Allan Schott, siapa yang membiayai kegiatan terorisme, seperti halnya tindak pidana yang lain menggunakan sistem keuangan nasional maupun internasional untuk menyembunyikan uang yang dipergunakan untuk aktifitas mereka, meskipun uang tersebut berasal dari sumber yang halal. Kriminalisasi semua aspek terorisme dan pembiayaan kegiatan terorisme adalah langkah praktis untuk mematahkan kekuatan organisasi teroris dengan cara mencegah uang mereka masuk ke dalam sistem keuangan negara. Tiap-tiap negara membutuhkan peraturan untuk membantu mendeteksi ketika ada dana-dana teroris sampai ke perbatasan agar uang tersebut dapat disita (Purwanto 2010: 126-127).

Selain itu, dirasakan masih minimnya regulasi yang dapat mempersempit ruang gerak aktifitas terorisme seperti: Pembuatan KTP dan dokumen perjalanan; Belum ada pembatasan aktifitas napi teroris dalam LP; Penggunaan telepon seluler dan internet; Pengaturan dan pengawasan tentang bahan peledak; Penertiban dan pengawasan terhadap kegiatan pelatihan militer oleh kelompok masyarakat; Pemberitaan tentang terorisme di media massa; Pengawasan terhadap kegiatan yang bersifat menghasut, menyebar kebencian dan memprovokasi untuk melakukan tindakan-tindakan permusuhan dan aksi kekerasan; dan Pengawasan lalu lintas orang dan barang di perbatasan dan pintu-pintu masuk dan keluar. (Menko Polhukkam 2006: 153-154).

Mempersempit ruang gerak aktifitas terorisme, berarti harus diambil tindakan oleh semua pihak yang terkait untuk memperbaiki, meregulasi serta menjalankan perbaikan permasalahan di atas. Dari permasalahan-permasalahan tersebut, yang berkaitan dengan perbankan adalah masalah KTP. Oegroseno pernah menyarankan kepada pejabat salah satu daerah untuk menerapkan nomor induk kependudukan tunggal (single identity number) yang tujuannya adalah dalam rangak mempersempit ruang gerak pelaku kejahatan (Yulhasni Siregar dan Arifin Saleh 2011: 57). 


\section{Simpulan dan Saran}

\section{Simpulan}

Berdasarkan uraian di atas, maka Pengaturan peran perbankan dalam pencegahan pembiayaan terorisme di Indonesia secara khusus tertuang dalam PBI II/2009 yang menyatakan pembiayaan terorisme merupakan penggunaan harta kekayaan secara langsung atau tidak langsung untuk kegiatan terorisme sebagaimana dimaksud dalam UU No. 8 Tahun 2010. Dengan demikian selain berdimensi tindak pidana terorisme, pengaturannya juga berada pada dimensi tindak pidana pencucian uang dan tindak pidana perbankan. Faktor pendukung peran perbankan dalam pencegahan pembiayaan terorisme di Indonesia dapat ditengahkan dalam aspek yuridis dan aspek sosial. Dalam aspek yuridis pendukung utamanya adalah substansi pencegahan pendanaan terorisme telah diatur sedemikian rupa dalam peraturan perundang-undangan sehingga dapat dijadikan dasar hukum bagi pelaksanaannya. Sedangkan dalam aspek sosiologis terdapat dukungan dunia internasional yang dilembagakan melalui konvensikonvensi pencegahan pendanaan terorisme sehingga menjamin kepastian hukum dan ketertiban dalam masyarakat.

\section{Saran}

Mengingat perkembangan tindak pidana terorisme yang diikuti pendanaan teroris semakin tinggi, maka perlu diimbangi dengan peningkatan kualitas penerapan manajemen risiko yang terkait dengan program anti pencucian uang dan pencegahan pendanaan terorisme yang mengacu pada prinsip-prinsip umum yang berlaku secara internasional, serta penyempurnaan penerapan prinsip mengenal nasabah oleh pihak perbankan. 


\section{DAFTAR PUSTAKA}

\section{Buku/Kamus:}

Adjie S. 2005. Terorisme. Jakarta: Pustaka Sinar Harapan.

Ali Masyhar. 2009. Gaya Indonesia Menghadang Terorisme. Bandung: Mandar Maju.

Andi Hamzah. 2010. Memburu Dana Teroris. Jakarta: CMB Press.

-. 2010. Terorisme di Indonesia Pasca Bom Marriott 2. Jakarta: CMB Press.

--------. 2009. Terminologi Hukum Pidana. Jakarta: Sinar Grafika.

--------. 2007. Terorisme Undercover, Memberantas Terorisme hingga ke Akarakarnya, Mungkinkah? Jakarta: CMB Press.

Bahder Johan Nasution. 2008. Metode Penelitian Ilmu Hukum, Bandung: CV. Mandar Maju.

Bambang Sunggono. 2011. Metodologi Penelitian Hukum. Jakarta: PT. Raja Grafindo Persada.

Burhan Bungin. 2007. Penelitian Kualitatif, Komunikasi, Ekonomi, Kebijakan Publik dan Ilmu Sosial lainnya. Jakarta: Kencana Prenada Media Group.

Departemen Pendidikan Nasional. 2008. Kamus Besar Bahasa Indonesia Pusat Bahasa. Jakarta: PT. Gramedia Utama.

Dzulqarnain M. Sunusi. 2010. Antara Jihad dan Terorisme, Pandangan Syar'i terhadap Terorisme, Kaidah-kaidah Seputar Jihad, Hukum Bom Bunuh Diri dan Studi Ilmiah Terhadap Buku Aku Melawan Teroris. Makassar: Pustaka As Sunah.

Erwin Asmadi. 2013. Pembuktian Tindak Pidana Teroris (Analisa Putusan Pengadilan Pada Kasus Perampokan Bank CIMB Niaga Medan). Medan: PT. Sofmedia.

Hendropriyono, A. M.. 2009. Terorisme, Fundamentalis Kristen, Yahudi, Islam. Jakarta: Buku Kompas.

Kaligis, O.C. 2003. Terorisme Tragedi Umat Manusia. Jakarta: O.C. Kaligis \& Associates.

Mardenis. 2011. Pemberantasan Terorisme, Politik Internasional dan Politik Hukum Nasional Indonesia. Jakarta: RajaGrafindo Persada.

Marjono Reksodiputro. 1994. Kemajuan Pembangunan Ekonomi dan Kejahatan, Kumpulan Karangan Buku Kesatu. Jakarta: Pusat Pelayanan Keadilan dan Pengabdian Hukum. 
Moch Faisal Salam. 2005. Motivasi Tindakan Terorisme. Bandung: Mandar Maju.

Muhammad Ali. 2006. Kamus Lengkap Bahasa Indonesia Moderen. Jakarta: Pustaka Amani.

Petrus Reinhard Golose. 2009. Deradikalisasi Terorisme: Humanis, Soul Approach dan Menyentuh Akar Rumput. Jakarta: Yayasan Pengembangan Kajian Ilmu Kepolisian-PTIK.

Romli Atmasasmita. 2000. Pengantar Hukum Pidana Internasional. Bandung: Refika Aditama.

Simorangkir, J. C. T., Dkk. 2002. Kamus Hukum. Jakarta: Sinar Grafika.

Soeharto. 2007. Perlindungan Hak Tersangka, Terdakwa, dan Korban Tindak Pidana Terorisme dalam Sistem Peradilan Pidana Indonesia. Jakarta: Refika Aditama.

Soerjono Soekanto dan Sri Mamudji. 2011. Penelitian Hukum Normatif Suatu Tinjauan Singkat. Jakarta: PT. Raja Grafindo Persada.

Sudarto. 1981. Kapita Selekta Hukum Pidana. Bandung: Alumni.

Tim Fokus Media. 2003. Pemberantasan Tindak Pidana Terorisme. Bandung: Fokus Media.

Wawan Purwanto. 2004. Terorisme Ancaman Tiada Akhir. Jakarta: Grafindo.

Yesmil Anwar dan Adang. 2010. Kriminologi. Jakarta: PT. Refika Aditama.

Siregar, Yulhasni dan Arifin Saleh. 2011. Oegroseno Pengabdian Polisi Tak Kenal Lelah. Jakarta: Prenada.

Zainuddin. 2011. Metode Penelitian Hukum. Jakarta: Sinar Grafika.

\section{Jurnal/Makalah:}

Kementrian Koordinator Bidang Politik. 2006. "Hukum dan Keamanan Republik Indonesia, Kebijakan dan Strategi Nasional Pemberantasan Terorisme". Makalah.

Yunus Husein. 2003. "PPATK: Tugas, Wewenang, dan Peranannya Dalam Memberantas Tindak Pidana Pencucuian Uang", Jurnal Hukum Bisnis. Volume 22 Nomor 3.

\section{Internet:}

Arief Setiawan. "Terorisme dalam Perspektif Hukum Internasional", http://www. ashlf.com, diakses pada tanggal 18 Maret 2016. 
Sitompul, Zulkarnain. 2007. "Tindak Pidana Perbankan dan Pencucian Uang (Money Laundring)". http://zulsitompul.files.wordpress.com. diakses pada tanggal 10 Januari 2012.

Yunus Husein, 2011, "Sosialisasi RUU tentang Pencegahan dan Pemberantasan Tindak Pidana Pendanaan Terorisme, Pusat Pelaporan dan Analisis Transaksi Keuangan”. www.ppatk.go.id. diakses pada tanggal 10 Januari 2012.

\section{Peraturan Perundang-undangan:}

Republik Indonesia, Undang-undang Nomor 7 Tahun 1992 sebagaimana telah diubah dengan Undang-undang Nomor 10 Tahun 1998 tentang Perbankan.

Republik Indonesia, Undang-undang Nomor 15 Tahun 2003 tentang Penetapan Peraturan Pemerintah Pengganti Undang-undang Nomor 1 Tahun 2002 tentang Pemberantasan Tindak Pidana Terorisme Menjadi UndangUndang.

Republik Indonesia, Undang-undang Nomor 6 Tahun 2006 tentang Ratifikasi International Convention for the Suppression of the Financing of Terrorism.

Republik Indonesia, Undang-undang Nomor 21 Tahun 2008 tentang Perbankan Syariah.

Republik Indonesia, Undang-Undang Nomor 8 Tahun 2010 Tentang Pencegahan dan Pemberantasan Tindak Pidana Pencucian Uang.

Republik Indonesia, Peraturan Pemerintah Nomor 46 Tahun 2010 tentang Badan Nasional Penanggulangan Terorisme (BNPT).

Peraturan Bank Indonesia Nomor 3/10/PBI/2001 sebagaimana diubah terakhir dengan Peraturan Bank Indonesia Nomor 5/21/PBI/2003 mengenai Prinsip Mengenal Nasabah (Know Your Customer Principles).

Peraturan Bank Indonesia Nomor 11/28/PBI/2009 tentang Penerapan Program Anti Pencucian Uang dan Pencegahan Pendanaan Terorisme bagi Bank Umum

Keputusan Kepala Pusat Pelaporan dan Analisis Transaksi Keuangan Nomor KEP-13/1.02.2/PPATK/02/08 tentang Pedoman Identifikasi Transaksi Keuangan Mencurigakan Terkait Pendanaan Terorisme bagi Penyedia Jasa Keuangan. 


\section{BIODATA PENULIS}

$\begin{array}{ll}\text { Nama } & \text { : Erwin Asmadi, S.H., M.H } \\ \text { Pekerjaan } & \text { : Dosen Fakultas Hukum Universitas Muhammadiyah Sumatera } \\ & \text { Utara } \\ \text { Jabatan } & : \text { Asisten Ahli } \\ \text { Nomor HP } & : \text { 081376162410 } \\ \text { E-mail } & : \text { erwin.asmadi@ gmail.com } \\ \text { Alamat Kantor } & : \text { Jl. Muchtar Basri No. 3 Medan }\end{array}$ 